\title{
RECOMMENDATIONS AND STRATEGIES FOR THE ESTABLISHMENT OF A GUIDELINE FOR MONUMENT DOCUMENTATION HARMONIZED WITH THE EXISTING EUROPEAN STANDARDS AND CODES
}

\author{
Anastasia KIOUSSI ${ }^{1}$, Kyriakos LABROPOULOS ${ }^{1}$, Maria KAROGLOU ${ }^{1}$, \\ Antonia MOROPOULOU ${ }^{1}$, Roko ZARNIC ${ }^{2}$ \\ ${ }^{1}$ National Technical University of Athens, School of Chemical Engineering \\ 9 Iroon Polytechniou Str. GR15870, Zografou Campus, Athens, Greece \\ nasiak@central.ntua.gr \\ ${ }^{2}$ University of Ljublijana, Faculty of Civil and Geodetic Engineering \\ Jamova cesta 2, SI-1000 Ljubljana, Slovenia
}

Keywords: cultural heritage, monument documentation, documentation, risk assessment indicators

\begin{abstract}
Information on current state of immovable cultural heritage is important for specifying measures necessary to preserve the heritage in an appropriate condition and ensure that the maintenance required to keep it at this level is well defined. In this framework, EU-CHIC project aims to set-up a system introducing a concept of the "Cultural Heritage Identity Card", which will develop into a systematic collection and storage of data on immovable heritage objects across European and neighboring countries. This work supports sustainable maintenance, preservation and revitalization of historic sites and monuments. This is achieved through the development of a guideline for the assessment of efficient documentation systems that identify the parameters needed for the characterisation of the preservation state of a monument and its possible alterations during its entire lifetime. In order to develop and test the recommendations for efficient compilation of the data pertinent to each monument under observation, the development of criteria, indicators and protocols as part of a common methodology that encourages the exchange of document between European countries is initiated. The criteria encompass all potential factors affecting the building structure, the non-structural elements, the architectural value and any other aspects ranging from the functionality of the monument/building, to its historic value. This has been achieved through an integrated survey of existing documentation protocols in the field of cultural heritage protection, and through implementation of recommendations about criteria for harmonizing these protocols, both which provide a new documentation methodology. This new methodology is an upgrade of current documentation methodologies, and responds to criteria and indicators for risk assessment and the technology state of diagnostics and data management. A guideline will provide the essential document for further development of European policies for the traceability of cultural assets and harmonization of criteria for the future maintenance of European Cultural Heritage.
\end{abstract}

\section{INTRODUCTION}

Cultural Heritage Protection is a multidisciplinary field that relies heavily on data compilation and processing. In order to support the continual process of sustainable maintenance, preservation and revitalization of historic sites and monuments, there exists a pressing need to collect and record reliable data on European cultural heritage. However, this is often difficult to achieve. In this framework, the EU-CHIC project has been initiated and aims to set-up a system introducing the concept of the "Cultural Heritage Identity Card", which will develop into a systematic collection and storage of data on immovable heritage objects across European and neighbouring countries. Recommendations for the assessment and application of efficient systems are developed that identify the parameters needed for the characterisation of the preservation state of a monument and its possible alterations during its entire lifetime. Such a concept is expected to have a significant cost benefit for cultural heritage owners and managers by using common parameters, and will increase the level of professional know-how in order to minimize the detrimental impact of lack of knowledge and expertise. Based on previous work and experience in the field by the National Technical University of Athens [1, 2], recommendations and strategies for monuments' documentation, harmonized with the existing European standards and codes are developed. In order to develop and test the recommendations needed for the efficient compilation of the data pertinent to each monument under observation, the first part of the work focuses on the 
development of criteria, indicators and protocols as part of a common methodology that encourages the exchange of document between European countries. The criteria encompass all potential factors affecting the building structure, the non-structural elements, the architectural value and any other aspects ranging from the functionality of the monument/building, to its historic value. This is achieved through an integrated survey of existing documentation protocols in the field of cultural heritage protection, and through implementation of recommendations about criteria for harmonizing these protocols, both which provide a new documentation methodology. This new methodology is an upgrade of current documentation methodologies, and responds to criteria and indicators for risk assessment and the technology state of diagnostics and data management.

\section{STATE OF THE ART}

\subsection{Survey of existing documentation protocols}

There exists no established universal documentation protocol/system for cultural heritage. This has also been identified by COST C5 Action which concluded that there are great variations in the systems of establishing and evaluating data from buildings in the European countries. In general, the responsibility for collecting data depends on the administrative structure in each country. As part of the development of European-level integrated documentation protocols, a survey of existing documentation protocols was performed to assess the current state-of-the-art in this field. The EU-CHIC project partners [3] studied twenty-three information systems from eleven European countries (Belgium, Czech Republic, Germany, Greece, Italy, Luxemburg, Malta, Poland, Portugal, Slovenia, Spain) and Israel. The following table presents a brief description of the systems analysed.

\begin{tabular}{|c|c|}
\hline $\begin{array}{l}\text { Geographic } \\
\text { location of usage }\end{array}$ & Documentation protocol \\
\hline \multirow{6}{*}{ Belgium } & VIOE - Vlaams Instituut voor het Onroerend Erfgoed [4] \\
\hline & Database of Cultural Heritage in the Brussels Region [5] \\
\hline & Database of the Cultural Heritage in the Walloon Region [6] \\
\hline & Monumentenwacht Vlaanderen [7] \\
\hline & $\begin{array}{l}\text { Cities of Bruges and Antwerp: Inspection of the buildings owned by the - heritage and } \\
\text { others - aiming at the maintenance of these buildings }\end{array}$ \\
\hline & $\begin{array}{l}\text { Ministry of Education of the Flemish Government: Methodology for the inspection and } \\
\text { evaluation of the condition and the maintenance of school buildings }\end{array}$ \\
\hline Czech Republic & Integrovaný informační systém památkové péče (IISPP) [8 \\
\hline Germany & ADABweb - Allgemeine Denkmaldatenbank [9] \\
\hline \multirow{4}{*}{ Greece } & National Archive of Monuments Information System (POLEMON) [10] \\
\hline & $\begin{array}{l}\text { Ministry of Culture / Directorate of Byzantine and Postbyzantine Monuments: ARCHI- } \\
\text { MED Risk Map of cultural heritage and mapping and description of cultural landscape }\end{array}$ \\
\hline & $\begin{array}{l}\text { Ministry of Culture: Technical Reports for museum interventions, extensions, upgrades } \\
\text { or new buildings }\end{array}$ \\
\hline & Acropolis Restoration Service (YSMA) [11] \\
\hline Israel & Site Card \\
\hline \multirow{2}{*}{ Italy } & Sistema Informativo Generale per il Catalogo (SIGEC) [12] \\
\hline & Carta del Rischio [13] \\
\hline Luxemburg & $\begin{array}{l}\text { Inventory of the cultural Heritage in the Grand-Duchy of Luxemburg (buildings and } \\
\text { landscapes) [14] }\end{array}$ \\
\hline Malta & Compilation of data inventory cards - National Protective Inventory [15] \\
\hline \multirow{2}{*}{ Poland } & Karta Cmentarza \\
\hline & 1. Krajowa Ewidencja Zabytków, 2. Krajowy Rejestr Zabytków \\
\hline Portugal & IGESPAR PT \\
\hline Slovenia & Cultural Heritage Register [16] \\
\hline \multirow{2}{*}{ Spain } & Ficha de Patrimonio Etnológico en Castilla y Leon \\
\hline & Inventario de Patrimonio Industrial de la Provincia de Valladolid \\
\hline
\end{tabular}

Table 1: Surveyed Documentation Protocols 
A detailed study of these protocols has been done to collect a meaningful sample of the existing information on Cultural Heritage protocols. Each one of these protocols follows unique procedures. However, these methodologies have been compared in order to draw conclusions concerning the best way to develop a hypothetically optimal procedure. This study focused on issues relating to the preservation and sustainability of Cultural Heritage, such as location of the building, monitoring processes, management, current state of preservation, materials and intervention techniques applied in the past, all aiming to document the complete history of the monument. The systems described in Table 1 are a compilation of two types of protocols: Documentation Systems and Risk Assessment Systems. Some protocols may belong to both types.

\subsection{Other Information Systems}

Data about cultural heritage are being collected, managed and presented by many different bodies with varying purpose, range of coverage and level of details. International perspective is important in research and development, coordination of activities and standardisation. The international view and safeguarding approach is interesting in comparison to the current administrative approach of the national information systems and databases. Some of the well recognised approaches are the Core Data Index to Historic Buildings and Monuments of the Architectural Heritage [17], the UNESCO's World Heritage List [18], the European Heritage Network [19], the Council of Europe [20], ICOMOS [21], the Getty Conservation Institute [22] and RecorDIM [23].

\subsection{European Policies, Standards and Directives}

Furthermore any recommendation and strategies developed for the establishment of a monument documentation guideline should conform to existing European Policies, standards and Directives. Tables 2 and 3 summarize respectively the main EC Policies and Directives, among those applicable to cultural heritage protection and management, with an impact on documentation. In addition to the above policies and directives, consideration should be given to the standard CEN/TC 346. European Committee for Standardization (CEN) is a major provider of European Standards and technical specifications [24]. It is the only recognized European organization according to Directive 98/34/EC for the planning, drafting and adoption of European Standards in almost all areas of economic activity. CEN's National Members work together to develop voluntary European Standards (ENs). The standard CEN/TC 346 has been recently submitted to the CEN Enquiry and concerns "Conservation of Cultural Property - Condition survey of immovable heritage". As such it can also be considered as a guideline for a common and standardized procedure to describe the condition state of built heritage. The Technical Committee CEN/TC 346 aims to develop a European standard that gives guidelines for a condition survey of an immovable cultural heritage object. It states how an immovable cultural heritage object should be registered, examined, documented and reported on.

\section{RECOMMENDATIONS AND STRATEGIES}

The survey on existing information systems at National, European and International level, as well as the detailed review of the state of the art on methodology and directives currently employed and applied in the field of documentation, both help to identify the most common and effective Methods and Tools for collection of data related to monument documentation. In addition, the critical issues for developing recommendations and strategies for directives, relating to cultural heritage protection, management and decision making are identified allowing the necessary adjustments to specific needs. The results are presented in Table 4. In order for any new guideline for monument documentation to be effective and widely applicable, not only it needs to be harmonized with existing European standards and codes but also, most importantly, be able to cater for the variety and the particularity of cultural heritage. This is achieved by selecting and integrating common criteria that formulate a dynamic archive, incorporating and supplying with information on the monument, during its entire life-time. The vital stage is the inclusion of all existing data concerning special building documentation, materials and building's structure, environmental factors, degradation mechanisms, diagnosis techniques and methods and intervention works as described above. A detailed description of the categories and subcategories presented in Table 1 will be included in the Final Report of the EU-CHIC project [3] pending feedback from the Network of Researchers (experts from all over Europe dealing with documentation protocols used for cultural heritage protection) and the Advisory Network (representatives of national authorities established in European countries, dealing with cultural heritage protection). It should be noted that documentation criteria and risk indicators identified within the existing protocols are focusing mainly on the macroscale of the monuments. In fact, they should not be limited to simply record information and risks associated with environmental dangers, human impact and natural hazards affecting the static/ structural state of the monument, but should include other factors such as the conservation state of the materials (i.e. not only the static/structural aspects of the building), the importance and distribution of cultural heritage, the impact factor of the hazards present, various socioeconomic parameters etc. Obviously, these factors cover different scales of the problem. In particular, there is a correlation between decay and damage of materials that often leads to the monuments pathology. Since the materials' state of conservation depends on their physicochemical and physicomechanical parameters and the materials' behavior in a corrosive environment is not 
generalized, the risk assessment should be dealt in the direction of revealing the specific active decay mechanism with an integrated decay study both in mesoscale [type of decay (morphology)] and microscale [kinetics of the phenomenon (decay rate) and thermodynamics of the phenomenon (susceptibility to decay)] level, through a Standardized Diagnostic Study Methodology [37, 38].

\begin{tabular}{|c|c|}
\hline EC Policies & Remarks \\
\hline \multicolumn{2}{|l|}{ Cultural Heritage } \\
\hline $\begin{array}{l}\text { Article 151 - EC Treaty (Maastricht (1992)): Contribute to } \\
\text { the flowering of the cultures of the Member States, while } \\
\text { respecting their national and regional diversity and at the } \\
\text { same time bringing the common } \mathrm{CH} \text { to the fore. Preservation } \\
\text { and enhancement of } \mathrm{CH} \text { [25] }\end{array}$ & $\begin{array}{l}\text { The importance of future refurbishment, } \\
\text { rehabilitation and maintenance of the built } \\
\text { heritage with regards to local and regional } \\
\text { development }\end{array}$ \\
\hline $\begin{array}{l}\text { Article } 17 \text { of The Convention for Protection of Cultural } \\
\text { Heritage in Europe: Investment in Research in Cultural } \\
\text { Heritage [26] }\end{array}$ & \multirow{3}{*}{$\begin{array}{l}\text { Reinforcement of research at European level } \\
\text { and provision of appropriated inputs to } \\
\text { establish effective \& compatible restoration } \\
\text { and conservation rules, by establishing a } \\
\text { system to catalogue the cultural heritage } \\
\text { assets and their elements, and to establish } \\
\text { authenticity and historic tracks of the } \\
\text { European Cultural Heritage }\end{array}$} \\
\hline $\begin{array}{l}\text { London Declaration for Improving CH Research: An } \\
\text { initiative to protect and safeguard European Cultural heritage } \\
\text { through scientific and technological research [27] }\end{array}$ & \\
\hline $\begin{array}{l}\text { Working Paper - STOA Unit: Technological requirements } \\
\text { for solutions in the conservation and protection of historical } \\
\text { monuments and archaeological remains [28] }\end{array}$ & \\
\hline $\begin{array}{l}\text { Council Resolution, OJ C 32, 2002, 21/01/2002: The role of } \\
\text { culture in the development of the European Union [29] }\end{array}$ & $\begin{array}{l}\mathrm{CH} \text { as a valuable asset for socioeconomic } \\
\text { development of Europe }\end{array}$ \\
\hline $\begin{array}{l}\text { Council Resolution, OJ C 136, 2003, 26/05/2003: The } \\
\text { horizontal aspects of culture: increasing synergies with other } \\
\text { sectors and exchange good practices in social and economic } \\
\text { dimensions [30] }\end{array}$ & $\begin{array}{l}\text { Multidisciplinary approach to consider all } \\
\text { the aspects related to Cultural Heritage, } \\
\text { including socio-economic aspects. It is } \\
\text { linked to the construction field through the } \\
\text { European Construction Technology } \\
\text { Platform (ECTP) }\end{array}$ \\
\hline \multicolumn{2}{|c|}{$\begin{array}{l}\text { Sustainability and Environmental policies } \\
\end{array}$} \\
\hline $\begin{array}{l}\text { Water Framework Directive : Civil protection to be taken } \\
\text { in relation to cultural heritage [31] }\end{array}$ & $\begin{array}{l}\text { Proper Identity Card system to protect } \\
\text { valuable assets. }\end{array}$ \\
\hline $\begin{array}{l}\text { EC CAFE initiative (Clean Air for Europe): The effects of } \\
\text { air pollution on cultural heritage. Protect and improve the } \\
\text { built environment and cultural heritage, and promote } \\
\text { biodiversity. [32] }\end{array}$ & $\begin{array}{l}\text { Promoting integrity of building envelop and } \\
\text { surrounding environment. }\end{array}$ \\
\hline $\begin{array}{l}\text { Treaty of Amsterdam (1997) \& Brussels European } \\
\text { Council (2003): The development that meets the needs of the } \\
\text { present without compromising the ability of future } \\
\text { generations to meet their own needs [33] }\end{array}$ & $\begin{array}{l}\text { The implementation of good practices to } \\
\text { promote sustainable conservation of } \\
\text { Cultural Heritage and proper adaptation to } \\
\text { new needs. }\end{array}$ \\
\hline $\begin{array}{l}\text { EIA Directive (97/11/EC) amending (85/337/EEC): } \\
\text { Assessment of the environmental effects of those public and } \\
\text { private projects which are likely to have significant effects on } \\
\text { the environment [34] }\end{array}$ & $\begin{array}{l}\text { The interaction of cultural heritage with the } \\
\text { environment, including natural landscapes. }\end{array}$ \\
\hline $\begin{array}{l}\text { Environmental Technologies Action Plan: Stimulating } \\
\text { technologies for Sustainable Development [35] }\end{array}$ & $\begin{array}{l}\text { Introduction of high measuring technologies } \\
\text { applicable to Cultural Heritage }\end{array}$ \\
\hline \multicolumn{2}{|l|}{ Tourism } \\
\hline $\begin{array}{l}\text { Article 3(1)u of the Treaty of Maastricht: Measures in the } \\
\text { sphere of tourism [36] }\end{array}$ & $\begin{array}{l}\text { Development of sustainable and compatible } \\
\text { exploitation of Cultural Heritage, with } \\
\text { tourism being a major issue. }\end{array}$ \\
\hline
\end{tabular}

Table 2: EC Policies considered for the development of harmonization criteria for the guideline for monument documentation 


\begin{tabular}{|l|l|}
\hline Directive & Remarks \\
\hline $\begin{array}{l}\text { Construction Products } \\
\text { 89/106/EEC }\end{array}$ & $\begin{array}{l}\text { Requires standardisation of construction products. This is a threat to some } \\
\text { traditional building materials and traditional conservation methods. }\end{array}$ \\
\hline $\begin{array}{l}\text { Energy E3/76/EEC } \\
\text { 93iciency }\end{array}$ & $\begin{array}{l}\text { Requires application of ventilation in old buildings. General indoor climate } \\
\text { requirements are hard to fulfill for old buildings without also affecting the } \\
\text { cultural value. }\end{array}$ \\
\hline $\begin{array}{l}\text { Environmental Impact } \\
\text { Assessment 85/337/EEC }\end{array}$ & $\begin{array}{l}\text { Assessing certain public and private projects on the environment. } \\
\text { Controversial when related to mixed areas of cultural and natural heritage. }\end{array}$ \\
\hline Lifts 95/16/EEC Habitats & $\begin{array}{l}\text { Concerning lifts permanently in service. Requirements for accessibility of } \\
\text { disabled persons can be a problem fulfilling in protected buildings without } \\
\text { also affecting authenticity and cultural value. }\end{array}$ \\
\hline $\begin{array}{l}\text { Natural } \\
\text { 92/43/EEC } \\
\text { disturbing CH values in a habitat protected by the directive cannot be } \\
\text { removed. CH values in these areas must succumb to the conflicting nature } \\
\text { interests. }\end{array}$ \\
\hline $\begin{array}{l}\text { Proposal for Directive on } \\
\text { Geographic information in } \\
\text { the EU (INSPIRE) COM } \\
\text { (2004)516 }\end{array}$ & $\begin{array}{l}\text { Wishes to establish a unified system for geographic information in Europe, } \\
\text { for monitoring and safeguarding of nature areas and pollutions control. CH } \\
\text { objects and buildings not included, and consequently will not be included in } \\
\text { the planning tools emerging from this unified GIS system. }\end{array}$ \\
\hline $\begin{array}{l}\text { Art 87-89. ( EU Treaty } \\
\text { Rome 1957). ). EEA treaty } \\
\text { art. 61. Rules on state aid }\end{array}$ & $\begin{array}{l}\text { Rules on state aid interfere with transfer of cultural heritage properties to non- } \\
\text { profit organizations / foundations and state funding of CH in general. }\end{array}$ \\
\hline
\end{tabular}

Table 3: Selective Directives considered for the development of harmonization criteria for the guideline for monument documentation

\begin{tabular}{|l|l|}
\hline Main category & Subcategories \\
\hline General description & $\begin{array}{l}\text { Formal / touristic name, national-international code number, current usage, context } \\
\text { and landscape, dating }\end{array}$ \\
\hline $\begin{array}{l}\text { Geographic } \\
\text { information }\end{array}$ & $\begin{array}{l}\text { Location, historic buildings and monuments ( individual / complex item), linear } \\
\text { structures, protected areas, archaeological sites and monuments ( individual / } \\
\text { complex item) }\end{array}$ \\
\hline $\begin{array}{l}\text { Ownership \& Legal } \\
\text { status }\end{array}$ & Ownership status, legal protection status, relevant legislation \\
\hline $\begin{array}{l}\text { Historical } \\
\text { documentation }\end{array}$ & $\begin{array}{l}\text { Historical resources research, archaeological survey, dating methods, construction } \\
\text { history, conservation history }\end{array}$ \\
\hline $\begin{array}{l}\text { Architectural } \\
\text { Documentation }\end{array}$ & $\begin{array}{l}\text { Architectural type, building elements, materials, building techniques, decoration, } \\
\text { electromechanical elements, movable objects, }\end{array}$ \\
\hline $\begin{array}{l}\text { Surveying and } \\
\text { documentation }\end{array}$ & $\begin{array}{l}\text { Detailed scale plans, realistic 2d depictions, realistic 3d depictions, visual } \\
\text { observations }\end{array}$ \\
\hline $\begin{array}{l}\text { Materials condition } \\
\text { and structural health } \\
\text { assessment }\end{array}$ & $\begin{array}{l}\text { Maintenance inspections, diagnostic surveys, phenomena \& mechanisms of decay, } \\
\text { building areas \& sampling, non destructive \& analytical techniques testing }\end{array}$ \\
\hline Interventions & $\begin{array}{l}\text { Construction phases, conservation history, restoration interventions, repair } \\
\text { materials \& techniques }\end{array}$ \\
\hline Outer effects impact & $\begin{array}{l}\text { Long term environmental effects, environmental change, anthropic impact and } \\
\text { improper use, disasters (floods / landslides / wind, storms and hurricanes / } \\
\text { earthquakes and tsunamis / fire / others / avalanches / volcanoes), dangers (coastal } \\
\text { dynamics), environmental factors (air / humidity / geological impact / surroundings } \\
\text { / flora \& fauna / erosion index / blackening index), anthropic (dynamics of } \\
\text { demographic density / tourism / liability to theft) }\end{array}$ \\
\hline
\end{tabular}




\begin{tabular}{|l|l|}
\hline Main category & Subcategories \\
\hline $\begin{array}{l}\text { Vulnerability and risk } \\
\text { management }\end{array}$ & $\begin{array}{l}\text { Preventive care, mitigations, monitoring, expert decision making system } \\
\text { (Inspection / Diagnosis / Intervention Indices) }\end{array}$ \\
\hline $\begin{array}{l}\text { Management, } \\
\text { Exploitation \& \& } \\
\text { Maintenance Planning }\end{array}$ & $\begin{array}{l}\text { Preservation plan, development \& exploitation plan, accessibility assessment, } \\
\text { schedule of maintenance inspections, integrated management through GIS }\end{array}$ \\
\hline Scientific research & Methods and Tools R\&D, thematic research and databases \\
\hline
\end{tabular}

Table 4: Main categories and subcategories of recording data for a documentation guideline

Furthermore, an effective documentation protocol should be able to respond to the necessity of performing inspection, diagnosis and intervention works, leading to knowledge based decision making procedures. It should also conform to the following requirements:

- Observance of the deontology of international conventions that demand the preservation and presentation of historic, sentimental virtues and the architecture of monuments, while preserving the authentic materials, forms and structures.

- Serviceability of the conservation interventions and restorations (so that the building can accept safely the new uses and face the earthquake risk)

- Compatibility of the materials and conservation interventions with authentic materials, the building and its environment

- Sustainability (Increase of lifetime, protection of the environment and energy savings, minimization of environmental impact on the monument)

Therefore, it has become obvious that the proposed guideline should not be a simply integration of existing projects, instead it should build upon current experiences and existing knowledge, encompassing all potential data regarding building structure, non structural elements, architectural value and all other aspects from functionality to historic value.

\section{CONCLUSIONS}

A combination of scientific, architectural, historic and cultural knowledge and experience of building conservation is indispensable for the study of all immovable cultural heritage objects reversing the current trend in focusing on specific aspects of documentation. An effective documentation protocol should be able to respond to the necessity of performing inspection, diagnosis and intervention works, leading to knowledge based decision making procedures. Based on existing initiatives, policies and directives that determine the established practice in the field of cultural heritage documentation, criteria were derived that will allow any new guideline for monument documentation to be harmonized with existing European Standards and codes. Such a standard methodology for monument documentation could bring the following advantages:

a) Standardized methodology in the EU countries means comparable data on the condition of Cultural Heritage in Europe,

b) Standardized data/ outputs are comparable (this means clearly defined database entry without any further need for definition) and

c) Translation of the standard by a national standardization committee provides a unified terminology.

In this context, the development of recommendations and strategies, as described in this work, is a vital step in establishing a guideline for monument documentation that will offer a unified methodology at a European level.

\section{REFERENCES}

[1] Moropoulou, A., Chandakas, B., Togkalidou, T., Karoglou, M., Padouvas, E., “A new methodology for quality control and monitoring of historic buildings: A tool for lifetime engineering", Symposium Proceedings, 2nd International symposium, ILCDES Integrated Life-time Engineering of Buildings and Civil Infrastructures, Kuopio, Finland (2003) pp. 269-274

[2] Togkalidou, T., Moropoulou, A., Karoglou, M., Padouvas, E., Chandakas, B., "System for Conservation Management of Historic Buildings incorporating quality control principles", ITECOM Conference on 'Innovative Technologies and Materials for the Protection of Cultural Heritage, Industry, Research, Education: European Acts and Perspectives', Technical Chamber of Greece, Athens (2003) pp. 365-376

[3] EU-CHIC Project website: http://www.eu-chic.eu/

[4] VIOE - Vlaams Instituut voor het Onroerend Erfgoed: www.vioe.be 
[5] Database of Cultural Heritage in the Brussels Region: www.irismonument.be

[6] Database of the Cultural Heritage in the Walloon Region: mrw.wallonie.be/dgatlp/ipa/

[7] Monumentenwacht Vlaanderen: www.monumentenwacht.be

[8] Integrovaný informační systém památkové péče (IISPP): https://iispp.npu.cz/

[9] ADABweb - Allgemeine Denkmaldatenbank: http://www.denkmalpflege-

bw.de/denkmale/datenbanken/adabweb.html

[10] National Archive of Monuments Information System (POLEMON):

http://nam.culture.gr/portal/page/portal/deam/erga/nam

[11] Acropolis Restoration Service (YSMA): http://www.ysma.gr

[12] Sistema Informativo Generale per il Catalogo (SIGEC): http://www.iccd.beniculturali.it

[13] Carta del Rischio: http://www.cartadelrischio.it/eng/index.html

[14] Inventory of the cultural Heritage in the Grand-Duchy of Luxemburg (buildings and landscapes):

www.ssmn.public.lu/patrimoine/index.html

[15] Compilation of data inventory cards which constitutes the National Protective Inventory: www.mepa.org.mt

[16] Cultural Heritage Register: http://rkd.situla.org/

[17] Core Data Index to Historic Buildings and Monuments of the Architectural Heritage. Recommendation R (95) 3 of the Committee of Ministers of the Council of Europe to member states on co-ordinating documentation methods and systems related to historic buildings and monuments of the architectural heritage. Strasbourg: Council of Europe, 1995.

[18] UNESCO’s World Heritage List: http://whc.unesco.org/en/list

[19] European Heritage Network:

http://www.european-heritage.net/sdx/herein/national_heritage/introduction.xsp

[20] Guidance on inventory and documentation of the cultural heritage, Council of Europe, (2009)

[21] International Council on Monuments and Sites: http://www.icomos.org/

[22] Getty Conservation Institute: http://www.getty.edu/conservation/

[23] Recording, Documentation and Information Management - An international Initiative for Historic Monuments and Sites: http://extranet.getty.edu/gci/recordim/

[24] European Committee for Standardization - TC 346: http://www.cen.eu/

[25] Article 151 - EC Treaty (Maastrich 1993): http://europa.eu.int/eur-lex/en/treaties/selected/livre234.html

[26] European Council, Reference texts in cultural heritage: Conventions:

http://www.coe.int/T/E/Cultural_Cooperation/Heritage/Resources/RefTxtCultHer.asp

[27] European Conference Declaration for Improving Cultural Heritage Research. International Conference Sustaining

Europe's Cultural Heritage: From Research to Policy. University College of London, EC Commission (2004)

www.ucl.ac.uk/sustainableheritage/conference-proceedings/london-declaration.html

[28] European Parliament. Directorate General For Research, Luxembourg, October 2001

[29] Council Resolution of 21 January 2002 on the role of culture in the development of the European Union. Official Journal C 032 , 05/02/2002 P. 0002 - 0002: http://europa.eu.int/eur-

lex/lex/LexUriServ/LexUriServ.do?uri=CELEX:32002G0205(02):EN:HTML

[30] Council Resolution of 26 May 2003 on the horizontal aspects of culture: increasing synergies with other sectors and Community actions and exchanging good practices in relation to the social and economic dimensions of culture. Official Journal C 136 , 11/06/2003 P. 0001 - 0002: http://europa.eu.int/eur-

lex/lex/LexUriServ/LexUriServ.do?uri=CELEX:32003G0611(01):EN:HTML

[31] Directive 2000/60/EC of the European Parliament and of the Council, establishing a framework for the Community action in the field of water policy. http://europa.eu.int/eur-lex/pri/en/oj/dat/2000/1_327/1_32720001222en00010072.pdf

[32] Communication from the Commission to the Council and the European Parliament - Thematic Strategy on air pollution - $\operatorname{COM}(2005) 446$ final, Brussels, 21.9.2005: http://europa.eu.int/eur-

lex/lex/LexUriServ/site/en/com/2005/com2005_0446en01.pdf

[33] The Amsterdam Treaty: http://europa.eu.int/scadplus/leg/en/s50000.htm

[34] Council Directive of 27 June 1985 on the assessment of the effects of certain public and private projects on the environment. 85/337/EEC. Official Journal NO. L 175 , 05/07/1985 P. 0040 - 0048:

http://europa.eu.int/comm/environment/eia/full-legal-text/85337.htm

[35] http://eur-lex.europa.eu/LexUriServ/site/en/com/2004/com2004_0038en01.pdf

[36] Article 3 (t) of the Treaty on European Union. Official Journal C 191, 29 July 1992 http://europa.eu.int/eurlex/lex/en/treaties/dat/11992M/htm/11992M.html

[37] Chandakas V., "Criteria and Methodology for the quality control of restoration works - protection of monuments and historic buildings", PhD Dissertation, (2004), National Technical University of Athens, supervisor Prof. A.

Moropoulou

[38] Kioussi A. "Development of a data base for the documentation of monuments and historic buildings. Integration into a system of total quality control, diagnostic and conservation intervention study", MSc Dissertation, (2005), National Technical University of Athens, supervisor Prof. A. Moropoulou 